\title{
PENGABDIAN MASYARAKAT STIKES WIDYAGAMA HUSADA MALANG DALAM PERCEPATAN VAKSINASI COVID-19 DENGAN KUNJUNGAN RUMAH DI WILAYAH KERJA PUSKESMAS KARANGPLOSO KABUPATEN MALANG
}

\author{
Ervin Rufaindah ${ }^{1)}$, Patemah ${ }^{1)}$, Yuliyanik ${ }^{1)}$ \\ 1)Program Studi D III Kebidanan, STIKES Widyagama Husada, Malang, Jawa Timur, Indonesia \\ Corresponding author : Ervin Rufaindah \\ E-mail : ervinrufaindah@yahoo.com
}

\section{Diterima 25 November 2021, Direvisi 12 Desember 2021, Disetujui 12 Desember 2021}

\begin{abstract}
ABSTRAK
Virus Corona atau severe acute respiratory syndrome coronavirus 2 (SARS CoV-2) adalah virus yang menyerang sistem pernapasan. Penyakit karena infeksi virus ini disebut COVID-19. Virus Corona bisa menyebabkan gangguan ringan pada sistem pernapasan, infeksi paru-paru yang berat, hingga kematian. Pandemi COVID-19 telah berdampak merugikan masyarakat, tidak hanya kesakitan dan kematian tetapi juga pada berbagai bidang sosial dan ekonomi. Vaksinasi atau imunisasi bertujuan untuk membuat sistem kekebalan tubuh seseorang mampu mengenali dan dengan cepat melawan bakteri atau virus penyebab infeksi. Tujuan yang ingin dicapai dengan pemberian vaksin COVID-19 adalah menurunnya angka kesakitan dan angka kematian akibat virus ini. Pengabdian masyarakat yang dilakukan oleh relawan Pengabdian Masyarakat STIKES Widyagama Husada ini memiliki tujuan yaitu untuk membantu percepatan vaksinasi di seluruh wilayah di Kabupaten Malang khususnya vaksinasi pada masyarakat cakupan wilayah Puskesmas Karangploso. Kegiatan Pengabdian Masyarakat ini dilakukan dengan pemberian dosis pertama dan dosis kedua. Pemberian vaksinasi dilakukan dengan kunjungan rumah dan sasarannya adalah lansia. Kolaborasi Abdimas STIKES Widyagama Husada Malang dengan tenaga medis di Puskesmas dan kader terjalin dengan baik, dengan indikator pelaksanaan kegiatan berjalan lancar dan tertib. Rangkaian prosedur kegiatan vaksinasi sebagai upaya percepatan vaksin covid-19 berjalan sesuai prosedur.
\end{abstract}

Kata kunci: covid 19; vaksinasi; pengabdian masyarakat.

\begin{abstract}
Corona virus or severe acute respiratory syndrome coronavirus 2 (SARS CoV-2) is a virus that attacks the respiratory system. The disease caused by this viral infection is called COVID-19. Corona virus can cause mild disorders of the respiratory system, severe lung infections, and even death. The COVID-19 pandemic has had a detrimental impact on society, not only in illness and death but also in various social and economic fields. Vaccination or immunization aims to make a person's immune system able to recognize and quickly fight bacteria or viruses that cause infection. The goal to be achieved by giving the COVID-19 vaccine is to reduce morbidity and mortality due to this virus. This community service carried out by the STIKES Widyagama Husada Community Service volunteer has a goal, namely to help accelerate vaccination in all areas in Malang Regency, especially vaccinations in the community coverage of the Karangploso Health Center area. This Community Service activity is carried out by giving the first dose and the second dose. Vaccination is carried out by home visits and the target is the elderly. The collaboration of Abdimas STIKES Widyagama Husada Malang with medical personnel at the Puskesmas and cadres is well established, with indicators that the implementation of activities runs smoothly and in an orderly manner. The series of procedures for vaccination activities as an effort to accelerate the Covid-19 vaccine run according to the procedure.
\end{abstract}

Keywords: covid 19; vaccination; community service

\section{PENDAHULUAN}

Virus Corona atau severe acute respiratory syndrome coronavirus 2 (SARS CoV-2) adalah virus yang menyerang sistem pernapasan. Penyakit karena infeksi virus ini disebut COVID-19. Virus Corona bisa menyebabkan gangguan ringan pada sistem pernapasan, infeksi paru-paru yang berat, hingga kematian. Severe acute respiratory syndrome coronavirus 2 (SARS-CoV-2) yang lebih dikenal dengan nama virus Corona adalah jenis baru dari coronavirus yang menular ke manusia. Virus ini bisa menyerang siapa saja, seperti lansia (golongan usia lanjut), orang 
dewasa, anak-anak, dan bayi, termasuk ibu hamil dan ibu menyusui. (Jayani et al., 2021)

Gejala awal infeksi virus Corona atau COVID-19 bisa menyerupai gejala flu, yaitu demam, pilek, batuk kering, sakit tenggorokan, dan sakit kepala. Setelah itu, gejala dapat hilang dan sembuh atau malah memberat. Penderita dengan gejala yang berat bisa mengalami demam tinggi, batuk berdahak bahkan berdarah, sesak napas, dan nyeri dada. Gejala-gejala tersebut muncul ketika tubuh bereaksi melawan virus Corona. Secara umum, ada 3 gejala umum yang bisa menandakan seseorang terinfeksi virus Corona, yaitu: Demam (suhu tubuh di atas 38 derajat Celsius), Batuk kering, dan Sesak napas. Upaya-upaya pencegahan dan penanganan telah gencar dilakukan pemerintah untuk memutus mata rantai penularan COVID-19 seperti: himbauan 5M (memakai masker, menjaga jarak, mencuci tangan, mengihndari kerumunan, dan mengurangi mobilisasi) dan upaya percepatan program Vaksinasi di masyarakat. (Asyafin et al., 2021)

Pandemi COVID-19 telah berdampak merugikan masyarakat, tidak hanya kesakitan dan kematian tetapi juga pada berbagai bidang sosial dan ekonomi. Efek pandemi dengan berbagai situasi yang berhubungan seperti pembatasan kegiatan, pembatasan perdagangan, pembatasan pergerakan, dan penguncian daerah menyebabkan terbatasnya kegiatan berbagai sektor produksi. Intervensi bidang kesehatan diawali dengan Pembatasan Sosial Berskala Besar dan pendidikan publik untuk mematuhi protokol kesehatan, diikuti gerak cepat pemerintah Indonesia untuk melaksanakan program vaksinasi COVID-19 secara nasional. (Mansyur, 2021)

Vaksinasi atau imunisasi bertujuan untuk membuat sistem kekebalan tubuh seseorang mampu mengenali dan dengan cepat melawan bakteri atau virus penyebab infeksi. Tujuan yang ingin dicapai dengan pemberian vaksin COVID-19 adalah menurunnya angka kesakitan dan angka kematian akibat virus ini. Meskipun tidak 100\% bisa melindungi seseorang dari infeksi virus Corona, vaksin ini dapat memperkecil kemungkinan terjadinya gejala yang berat dan komplikasi akibat COVID19. (Rahman, 2021)

$$
\text { Selain itu, vaksinasi COVID-19 }
$$

bertujuan untuk mendorong terbentuknya herd immunity atau kekebalan kelompok. Hal ini penting karena ada sebagian orang yang tidak bisa divaksin karena alasan tertentu. Jadi, dengan mendapatkan vaksin COVID-19, anda tidak hanya melindungi diri sendiri, tapi juga orang-orang di sekitar Anda yang belum memiliki kekebalan terhadap virus Corona.
Tujuan utama vaksinasi COVID-19 adalah mengurangi transmisi/penularan COVID19, menurunkan angka kesakitan dan kamatian akibat COVID-19. Mencapai kekebalan kelompok di masyarakat (herd imunity) dan melindungi masyarakat dari COVID-19 agar tetap produktif secara sosial dan ekonomi. (Ritunga et al., 2021)

Vaksinasi COVID-19 adalah bagian penting dari upaya penanganan pandemi COVID19 yang menyeluruh dan terpadu meliputi aspek pencegahan dengan penerapan protokol kesehatan: menjaga jarak, mencuci tangan pakai sabun dan memakai masker (3M), vaksinasi COVID-19, dan 3T (Tes, Telusur, Tindak lanjut). (Fauzia \& Hamdani, 2021)

Herd Immunity atau kekebalan kelompok akan terbentuk jika sebagian besar masyarakat divaksinasi. Cakupan vaksinasi yang tinggi membutuhkan partisipasi dan kerjasama berbagai pihak untuk mengatasi keengganan dan keraguan (hesitancy) masyarakat terhadap vaksinasi, meningkatkan penerimaan (acceptance) dengan memastikan ketersediaan akses pada informasi yang akurat tentang vaksinasi COVID-19. Pelaksanaan 3T (Tes, Telusur, Tindak lanjut) juga memerlukan kerjasama dari berbagai pihak guna memastikan mereka yang berisiko di tes, ditelusuri kemungkinan menularkan pada yang lain dan jika sakit diobati sampai sembuh sehingga dapat kembali produktif. (Prihartanti et al., 2021)

Hasil survei penerimaan vaksin yang dilakukan Kementerian Kesehatan bersama ITAGI (Indonesian Technical Advisory Group on Immunization) dengan dukungan UNICEF dan WHO pada bulan September 2020 menunjukkan bahwa sebagian besar masyarakat (74 persen) sudah mengetahui rencana pemerintah untuk melaksanakan vaksinasi COVID-19. Sebanyak 65 persen bersedia untuk divaksinasi, sekitar 27 persen masih ragu. Dan hanya sebagian kecil atau sekitar 8 persen yang menyatakan menolak dengan alasan khawatir akan keamanan, efektivitas dan kehalalan vaksin. Hasil survei juga menunjukkan bahwa mereka yang memiliki informasi tentang vaksinasi COVID-19 cenderung lebih menerima vaksinasi COVID-19. (Asyafin et al., 2021)

Hal ini menunjukkan pentingnya untuk memastikan seluruh masyarakat mendapatkan akses terhadap informasi yang akurat tentang penanganan COVID-19, termasuk tentang vaksinasi COVID-19. Pengabdian kepada masyarakat merupakan pelaksanaan pengamalan ilmu pengetahuan, teknologi dan seni budaya langsung pada masyarakat secara kelembagaan melalui metodologi ilmiah 
sebagai penyebaran Tri Dharma Perguruan Tinggi serta tanggung jawab yang luhur dalam usaha mengembangkan kemampuan masyarakat, sehingga dapat mempercepat laju pertumbuhan tercapainya tujuan pembangunan nasional. (Rahman, 2021)

$$
\text { Kegiatan pengabdian kepada }
$$

masyarakat secara umum meliputi ruang lingkup sebagai berikut: a) Pengembangan ilmu pengetahuan teknologi dan seni menjadi produk yang secara langsung dapat dimanfaatkan oleh masyarakat; b) Penyebarluasan ilmu pengetahuan, teknologi dan seni budaya menjadi produk yang perlu diketahui dan dimanfaatkan oleh masyarakat. Usaha ini dapat dilakukan melalui berbagai cara seperti memberikan penyuluhan, menyediakan percontohan, memperagakan, dan menerbitkan media publikasi; c) Penempatan ilmu pengetahuan dan teknologi secara benar dan tepat sesuai dengan situasi masyarakat dan tuntutan pembangunan; d) Pemberian bantuan kepada masyarakat dalam mengidentifikasi masalah yang dihadapi serta mencari alternatif pemecahannya dengan mempergunakan pendekatan ilmiah; e) Pemberian jasa pelayanan profesional kepada masyarakat dalam berbagai bidang permasalahan yang memerlukan penanganan secara cermat dengan menggunakan keahlian dan keterampilan yang belum dimiliki oleh masyarakat yang bersangkutan.

Pengabdian masyarakat yang dilakukan oleh relawan Pengabdian Masyarakat STIKES Widyagama Husada ini memiliki tujuan yaitu untuk membantu percepatan vaksinasi di seluruh wilayah di Kabupaten Malang khususnya vaksinasi pada masyarakat cakupan wilayah Puskesmas Karangploso. Selain mematuhi protokol kesehatan yang ada, sangat diperlukan dilakukan vaksinasi sebagai upaya pencegahan dan pengendalian covid 19 yang dapat memberikan perlindungan bagi masyarakat agar terhindar dari penularan Covid 19.

\section{METODE}

\section{Persiapan}

Pendataan Sasaran

Pendataan sasaran penerima vaksin dilakukan secara top-down, meliputi nama, Nomor Induk Kependudukan dan alamat tempat tinggal sasaran. Penyaringan data sehingga diperoleh sasaran kelompok penerima vaksin COVID-19 sesuai kriteria yang telah ditetapkan. Tempat pelaksanaan vaksinasi Covid-19 yaitu rumah warga (kunjungan rumah).

Perhitungan kebutuhan: Kebutuhan vaksin dan logistik vaksinasi (ADS, safety box, alcohol swab), Kebutuhan logistik Pencegahan dan
Pengendalian Infeksi dan Alat Pelindung Diri (Masker medis, Sarung tangan, Apron), Kebutuhan logitsik PPI (hand sanitizer, sabun cair, air mengalir, desinfektan), Kebutuhan materi KIE sesuai kebutuhan.

\section{Pelaksanaan}

Kegiatan pengabdian masyarakat oleh relawan Pengabdian Masyarakat STIKES Widyagama Husada Malang melalui kegiatan vaksinasi ini dilaksanakan di Desa Ngijo wilayah cakupan Puskesmas Karangploso Kabupaten Malang. Pemberian vaksinasi ini dilakukan secara kunjungan rumah. Sasaran vaksinasi kali ini adalah lansia. Vaksinasi dilaksanakan dengan memberikan dosis pertama dan dosis kedua. Sasaran vaksinasi dosis pertama adalah 150 orang dan dosis kedua diberikan kepada 85 orang. Pelaksanaan Vaksinasi secara kunjungan rumah tersebut didampingi oleh kader setempat.

Relawan Pengabdian Masyarakat STIKES Widyagama Husada Malang diberikan kesempatan untuk melakukan skrining dan pemeriksaan tekanan darah, suhu pada calon peserta yang akan divaksin, dan sebagai vaksinator. Alur kegiatan vaksinasi dimulai dari kunjungan rumah untuk melakukan vaksin. Relawan mendatangi calon peserta dengan didampingi oleh kader. Setelah tiba di rumah calon peserta vaksin, Calon peserta mendaftarkan diri terlebih dahulu dengan menyerahkan persyaratan untuk vaksin seperti salinan KK dan KTP. Selanjutnya peserta vaksin tersebut dilakukan skrining melalui pengukuran tekanan darah dan suhu. Kemudian jika kondisi peserta vaksin dalam kondisi baik dan memenuhi kriteria diperbolehkan vaksin, peserta vaksin selanjutnya dilakukan injeksi vaksin. Setelah di vaksin peserta vaksin dapat menunggu terlebih dahulu untuk mendapat kartu vaksin.

\section{Monitoring}

Memantau tingkat keberhasilan penyelenggaraan kegiatan di suatu lokasi secara cepat

\section{Evaluasi}

Pemantauan dampak imunisasi terhadap penularan COVID-19, Mengetahui keamanan, khasiat dan mutu vaksin. Masyarakat tampak antusias mengikuti kegiatan vaksinasi melalui kunjungan rumah ini. Hal ini terlihat saat dikunjungi, masyarakat sudah mempersiapkan diri dan persyaratan untuk vaksinasi sambil menunggu tim vaksinator datang. 


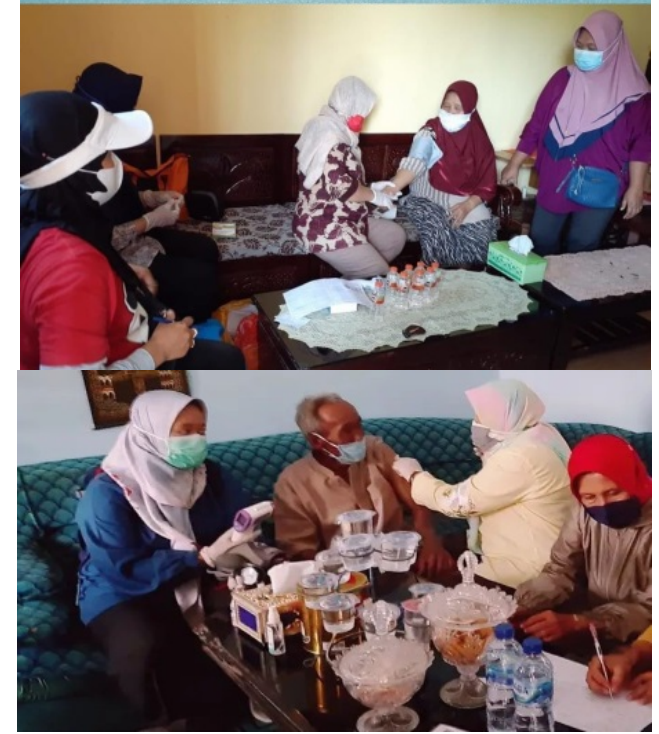

Gambar 1. Proses Pelaksanaan Kegiatan Skrinning Vaksinasi Dengan Kunjungan Rumah di Desa Ngijo

(Sumber : Relawan Pengabdian Masyarakat STIKES Widyagama Husada Malang)

\section{HASIL DAN PEMBAHASAN}

egiatan pengabdian masyarakat oleh abdimas STIKES Widyagama Husada Malang yang terdiri dari 3 orang dosen kebidanan ditugaskan untuk membantu kegiatan vaksinasi wilayah cakupan Puskesmas Karangploso. Kegiatan pengabdian masyarakat vaksinasi dilakukan dengan pemberian dosis pertama dan dosis kedua. Vaksinasi diberikan dengan kunjungan rumah dengan sasaran adalah lansia. Masyarakat sangat antusias mengikuti vaksinasi karena di datangi oleh tenaga vaksinator ke rumah mereka. Dengan bantuan kader setempat, masyarakat sudah siap dengan persyaratan untuk vaksinasi dan tinggal menunggu kedatangan tim vaksinator.

Langkah awal dilaksanakan kegiatan pengabdian masyarakat ini yaitu tim vaksinator mendatangi rumah calon peserta dengn bantuan kader, kemudian calon peserta menyerahkan salinan KTP dan salinan KK untuk di daftarkan. Selanjutnya peserta vaksin dilakukan skrining pemeriksaan tekanan darah dan suhu tubuh oleh relawan pengabdian masyarakat STIKES Widyagama Husada Malang. Skrining dilakukan dengan teknik wawancara dengan memberikan pertanyaan seputar riwayat dan keadaan calon peserta vaksin saat itu. Beberapa dari masyarakat tidak jadi mendapatkan vaksinasi karena belum memenuhi persyaratan untuk dilakukan vaksinasi, seperti saat di lakukan pemeriksaan Tekanan Darah sistole diatas $180 \mathrm{mmHg}$, pernah mengalami serangan jantung, memiliki riwayat epilepsi, atau memiliki penyakit penyerta lainnya.
Bagi peserta vaksin yang sudah memenuhi persyaratan setelah di skrining dan kondisinya baik untuk di vaksin, peserta vaksin dapat segera dilakukan vaksinasi yang dilakukan oleh relawan pengabdian masyarakat STIKES Widyagama Husada Malang. Setelah selesai tindakan vaksinasi, peserta vaksin dianjurkan untuk diobservasi selama 30 menit untuk memantau ada tidaknya efek samping yang timbul pasca penyuntikkan sembari menunggu kartu vaksin. Setelah semua tahapan setelah dilakukan vaksinasi peserta vaksin dianjurkan untuk tetap menerapkan protokol kesehatan dan tim vaksinator pindah ke rumah warga yang lain guna melakukan vaksinasi dengan sasaran berikutnya.

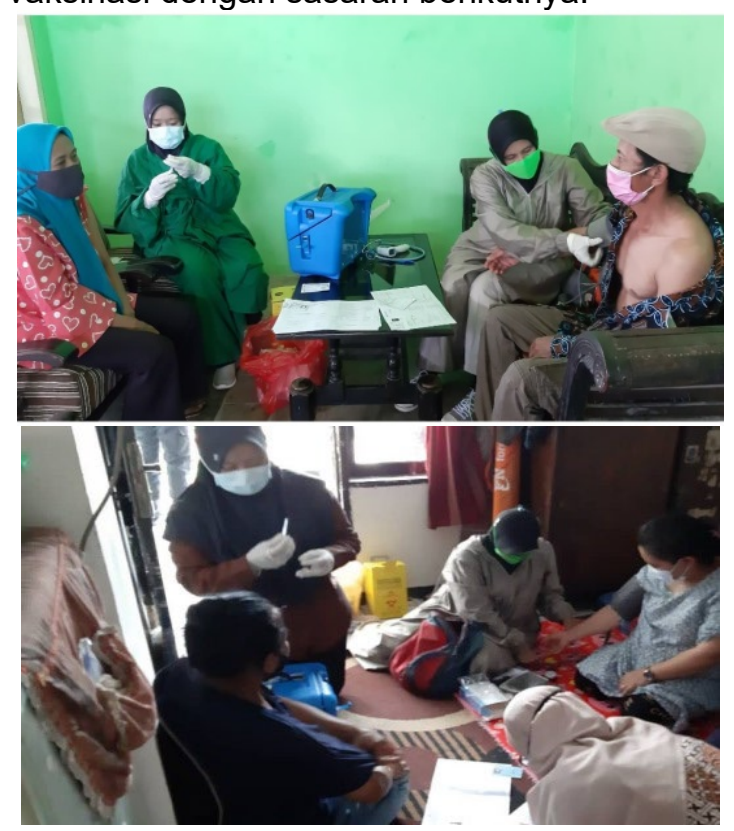

Gambar 2. Proses Pelaksanaan Kegiatan

Vaksinasi Dengan Kunjungan Rumah di Desa Ngijo

(Sumber : Relawan Pengabdian Masyarakat STIKES Widyagama Husada Malang)

Kegiatan pengabdian masyarakat ini tentu bermanfaat bagi masyarakat sebagai perwujudan upaya percepatan vaksinasi ini di wilayah kerja Puskesmas Karangploso Kabupaten Malang. Terutama bagi para lansia yang memiliki keterbatasan untuk mobilisasi atau kesulitan mengunjungi tempat layanan vaksinasi. Kegiatan ini juga memiliki manfaat bagi relawan pengabdian masyarakat STIKES Widyagama Husada Malang dalam mengimplementasikan pengabdian tenaga kesehatan dimasa pandemi ini. Dapat menambah wawasan ilmu, mendapat pengalaman yang luar biasa yang mungkin belum didapatkan sebelumnya, mengasah kemampuan berkomunikasi, dapat mengenal dan mempelajari lingkungan masyarakat yang 
lebih luas, serta dapat ikut serta dalam memutus rantai penyebaran Covid 19.

\section{SIMPULAN DAN SARAN}

egiatan Pengabdian Masyarakat oleh STIKES Widyagama Husada Malang sebagai vaksinator di wilayah Puskesmas Karangploso Kabupaten Malang dilakukan dengan pemberian dosis pertama dan dosis kedua. Pemberian vaksinasi dilakukan dengan kunjungan rumah dan sasarannya adalah lansia. Kolaborasi Abdimas STIKES Widyagama Husada Malang dengan tenaga medis di Puskesmas dan kader terjalin dengan baik, dengan indikator pelaksanaan kegiatan berjalan lancar dan tertib. Rangkaian prosedur kegiatan vaksinasi sebagai upaya percepatan vaksin covid-19 berjalan sesuai prosedur.

Diharapkan pengabdian masyarakat ini dapat diikuti oleh institusi pendidikan lain sehingga dapat membantu pemerintah dalam program percepatan vaksinasi guna memutus rantai penularan Covid-19.

\section{UCAPAN TERIMAKASIH}

Penulis mengucapkan terima kasih kepada STIKES Widyagama Husada Malang yang telah memfasilitasi dalam penyediaan APD. Penulis juga mengucapkan terima kasih kepada Puskesmas Karangploso yang telah memberikan kesempatan untuk ikut terlibat dalam kegiatan percepatan vaksinasi Covid19. Tidak lupa penulis juga berterima kasih kepada kader yang telah banyak membantu vaksinasi ini dan masyarakat yang ikut serta dalam kegiatan vaksinasi yang telah kooperatif dalam pelaksanaan kegiatan pengabdian masyarakat ini.

\section{DAFTAR RUJUKAN}

Asyafin, M. A., Virdani, D., Kasih, K. D., \& Arif, L. (2021). Implementasi Kebijakan Vaksinasi COVID-19 di Kota Surabaya. Journal Publicuho, 4(2), 501-510. https://doi.org/10.35817/jpu.v4i2.18061

Fauzia, A., \& Hamdani, F. (2021). Pendekatan Socio-Cultural dalam Pelaksanaan Vaksinasi Covid-19 di Indonesia. Seminar Nasional Hukum Universitas Negeri Semarang, 7(1), 323-338. https://doi.org/10.15294/snhunnes.v7i1.7 09

Jayani, I., Ramayanti, E. D., \& Susmiati. (2021). Edukasi Penerapan Protokol Kesehatan Pada Era New Normal Sebagai Bentuk Upaya Pencegahan Pengendalian Covid19. Jurnal ABDINUS : Jurnal Pengabdian Nusantara, 5(1), 1-8. https://doi.org/https://doi.org/10.29407/ja. v5i1.15270
Mansyur, M. (2021). Vaksinasi COVID-19 bagi Pekerja, Harapan Pulihnya Produktivitas. Journal of The Indonesian Medical Association, 71(1), 1-4. https://doi.org/10.47830/jinma-vol.71.12021-534

Prihartanti, N., Yujiani, R., Wardani, C. P. K., Muniroh, S., Marcelina, A. R., Arifah, P. L., \& Kurniawati, R. R. R. A. E. (2021). Relawan Abdimas STIKES Pemkab Jombang Dalam Percepatan Vaksinasi Covid-19 di Wilayah Kerja Puskesmas Cukir Kabupaten Jombang. Society, 2(2), 24-28.

https://doi.org/10.37802/society.v2i1.166

Rahman, Y. A. (2021). Vaksinasi Massal Covid19 sebagai Sebuah Upaya Masyarakat dalam Melaksanakan Kepatuhan Hukum (Obedience Law). Khazanah Hukum, 3(2), 80-86. https://doi.org/10.15575/kh.v3i2.11520

Ritunga, I., Lestari, S. H., Santoso, J. L., Effendy, L. V., Siahaan, S. C. P. T., Lindarto, W. W., Nurhadi, S., Irham, I. M. M., \& Monica, T. (2021). Penguatan Program Vaksinasi Covid-19 di Wilayah Puskesmas Made Surabaya Barat. Jurnal ABDINUS: Jurnal Penagbdian Nusantara, 5(1), 45-52. https://doi.org/10.29407/ja.v5i1.15953 